\title{
PAULO FREIRE, CENTÉSIMO ANO: MAIS QUE UM MÉTODO, UMA CONCEPÇÃO CRÍTICA DE EDUCAÇÃO
}

Dermeval SaViani ${ }^{1}$

\begin{abstract}
RESUMO: Ao ensejo do centenário do nascimento de Paulo Freire, este artigo mostra a relevância da concepção crítica de educação para o método de alfabetização e para a crítica à opressão vivida pela maioria da população na sociedade atual. Para isso, trata, no primeiro momento, do empenho de Freire na alfabetização e na conscientização das massas para a participação no desenvolvimento do país. No segundo momento, Freire abre-se para os esfarrapados do mundo e, mantendo-se como personalista cristão, estabelece profícua interlocução com o marxismo. Em conclusão, faz-se um paralelo entre a situação do país no exílio de Freire e o quadro atual, mostrando a perda que sua saída significou para a educação brasileira e o risco de perdermos até seu legado se persistir o retrocesso político em que nos encontramos.
\end{abstract}

Palavras-chave: Paulo Freire. Educação libertadora. Conscientização. Pedagogia do oprimido.

\section{PAULO FREIRE, ONE-HUNDRETH YEAR: MORE THAN A METHOD, A CRITICAL CONCEPTION OF EDUCATION}

\begin{abstract}
On the occasion of the centenary of Paulo Freire's birth, this article shows the relevance of the critical conception of education for the literacy method and for the critique of the oppression experienced by the majority of the population in present-day society. In order to achieve this, at first, we address Freire's commitment to literacy and awareness of the masses for participation in the country's development. In a second moment, Freire opens up to the rags of the world and, maintaining himself as a Christian personalist, establishes a fruitful dialogue with Marxism. In conclusion, a parallel is made between the situation of the country in Freire's exile and the current situation, showing the loss that his departure meant for Brazilian education, as well as the risk of losing even its legacy if the political setback in which we find ourselves persists.
\end{abstract}

Keywords: Paulo Freire. Liberating education. Awareness. Pedagogy of the oppressed.

1.Universidade Estadual de Campinas - Departamento de Filosofia e História da Educação - Faculdade de Educação - Campinas (SP), Brasil. E-mail: dermeval.saviani.2013@gmail.com

Editora de Seção: Ivany Pino 


\section{PAULO FREIRE, CIEN AÑOS: MÁS QUE UN MÉTODO, UNA CONCEPCIÓN CRÍTICA DE LA EDUCACIÓN}

RESUMEN: Con motivo del centenario del nacimiento de Paulo Freire, este artículo muestra la relevancia de la concepción crítica de la educación para el método de alfabetización y para la crítica de la opresión que vive la mayoría de la población en la sociedad actual. Por ello, se analiza, en un primer momento, el compromiso de Freire con la alfabetización y la concientización de las masas para la participación en el desarrollo del país. En el segundo momento, Freire se abre a los harapos del mundo y, manteniéndose como un personalista cristiano, establece un fructífero diálogo con el marxismo. En conclusión, se hace un paralelismo entre la situación del país en el exilio de Freire y la situación actual, mostrando la pérdida que significó su salida para la educación brasileña y el riesgo de perder incluso su legado si persiste el revés político en el que nos encontramos.

Palabras-clave: Paulo Freire. Educación liberadora. Conciencia. Pedagogía del oprimido.

\section{Introdução}

A

fama de Paulo Freire se encontra fortemente associada ao método de alfabetização de adultos por ele criado. É verdade que, internacionalmente, sua notoriedade decorre predominantemente do livro Pedagogia do oprimido haja vista ter sido publicado em dezessete diferentes idiomas. No Brasil, porém, seu nome sempre se vincula ao método de alfabetização na forma do "método Paulo Freire". Entretanto, já em seus primeiros escritos, encontramos uma clara concepção de homem, sociedade e educação que está na base do método e sem a qual esse não pode ser adequadamente compreendido. Na sequência, procuraremos explicitar essa proposição em dois momentos. No primeiro, destacam-se a tese de concurso Educação e atualidade brasileira e o livro Educação como prática da liberdade. No segundo, sobressai a obra Pedagogia do oprimido, seguida de outros trabalhos, com destaque para Ação cultural para a liberdade.

\section{Alfabetização e Conscientização das Massas para o Desenvolvimento Nacional}

A concepção de homem, sociedade e educação mencionada anteriormente já fora esboçada no primeiro trabalho de Freire, Educação e atualidade brasileira (1959), tese apresentada ao concurso para a Cadeira de História e Filosofia da Educação da Escola de Belas Artes de Pernambuco, integrante da então Universidade do Recife, que, em 1967, transformou-se na atual Universidade Federal de Pernambuco. O texto foi estruturado com uma introdução, de dezesseis páginas, três capítulos não nomeados, uma conclusão e dois pequenos anexos. O primeiro capítulo se estende por 29 páginas; o segundo, por 23; o terceiro, por 31; e a conclusão, por duas páginas. Nessas duas páginas conclusivas, já se antecipavam as linhas mestras da sua concepção de homem, sociedade e educação, tendo como referência a situação brasileira, conforme os seguintes enunciados, cujo significado apresentaremos conjugando no passado os verbos que evidentemente Freire colocava no presente do indicativo:

1. Para ser instrumento de mudança social, a educação precisava manter relação orgânica com o contexto da sociedade em que se encontrava; 
2. Essa relação orgânica implicava um conhecimento crítico da realidade para que a educação pudesse se integrar a ela e não a ela se superpor;

3. Sua superposição à realidade, decorrente de transplantes sem a necessária adequação à nova circunstância, tornava a educação inautêntica e, por isso, inoperante;

4. A atualidade brasileira então se caracterizava por uma sociedade em trânsito de uma economia comandada pelo comércio exterior para uma economia de mercado, com o predomínio de um capitalismo florescente; de formas rigidamente antidemocráticas para formas plasticamente democráticas, em antinomia umas com as outras;

5. A antinomia básica de nossa atualidade representava aqueles dois climas, o da economia voltada ao comércio exterior, com formas políticas antidemocráticas, e o da economia de mercado, com o surto de industrialização que favorecia a emergência de formas democráticas. O primeiro clima era, portanto, o da nossa "inexperiência democrática"; o segundo, o da "emersão do povo na vida pública brasileira";

6. Na medida em que se acelerava o ritmo de industrialização, a emersão do povo se fazia mais vigorosa, passando da condição de expectador à de participante e evoluindo, assim, de uma consciência intransitiva para a transitivo-ingênua;

7. Essa transitividade precisava ser promovida pela educação à crítica, a qual, fundando-se na razão, não devia significar uma posição racionalista, mas uma abertura do homem pela qual, mais lucidamente, pudesse ver seus problemas - posição que implicava a libertação do homem de suas limitações pela consciência delas;

8. A não promoção da ingenuidade para a criticidade implicava uma distorção da consciência popular a formas desumanizadas que levavam o homem a posições mágicas e míticas, o que comprometia o caráter permeável e plástico próprio da mentalidade democrática;

9. O novo clima cultural, em elaboração, exigia o exercício da participação e da decisão do homem nacional no acontecer histórico do país, razão por que se fazia necessária uma planificação democrática em que houvesse lugar para vasto trabalho de educação extraescolar, dirigida no sentido da democracia;

10. O processo educativo brasileiro vinha sendo uma superposição à realidade então vivida, porque: a) não atendia à transição de formas econômicas, que requeria toda uma revisão da educação no sentido da formação de técnicos dos vários níveis, como de mão de obra qualificada; b) não atendia à necessidade imperiosa de identificar o homem brasileiro com o ritmo de democratização política e cultural, criando-lhe disposições mentais democráticas, com que superasse nossa ostensiva "inexperiência democrática”. O seu verbalismo e o seu sentido seletivo e florido eram contradições e obstáculos às forças democráticas em emersão;

11. Finalmente, Paulo Freire entendia que a revisão de nosso processo educativo não podia ser parcial porque era todo ele que estava inadequado e era de todo ele, em conjunto, em bloco, que a cultura em elaboração precisava (FREIRE, 1959, p. 122-123).

Vê-se que o horizonte da concepção pedagógica freireana, ao menos até 1965, quando concluiu a redação de Educação como prática da liberdade, era a sociedade industrial impulsionada economicamente pelo capitalismo de mercado, sob a forma política da democracia liberal em consonância com a visão 
nacional-desenvolvimentista. Conforme Vanilda Paiva, tratava-se de uma "síntese pedagógica existencialculturalista" que articulava as ideias filosóficas do personalismo cristão com a filosofia da existência e o culturalismo político dos isebianos históricos. Dessa forma, fundamentando o pensamento católico na ligação do personalismo com o culturalismo forjou-se a interpretação da realidade brasileira a partir de seu passado colonial como base para a formulação de uma "pedagogia existencial culturalista" que, orientada pelo personalismo cristão, estimulou a comunicação de consciências para superar a massificação em direção à emersão do povo na vida político-social do país (PAIVA, 1980, p. 28-118).

O conteúdo da tese de concurso supracitada foi incorporado, com os devidos ajustes, aos três primeiros capítulos do livro Educação como prática da liberdade, cuja redação foi concluída em 1965, já durante o exílio de Freire no Chile, livro que foi publicado no Brasil em 1967. No primeiro capítulo, "A sociedade brasileira em transição", expõe-se o que chamei de “Teoria do Trânsito" (SAVIANI, 2021, p. 322323), apresentada por meio de uma terminologia composta por pares antitéticos e esclarecendo, assim, a situação da sociedade brasileira, que transitava de uma condição para outra. Apresentei, então, os pares de conceitos colocando, à esquerda, os termos próprios da velha situação e, à direita, aqueles que correspondiam à nova situação. A passagem, isto é, o trânsito, estaria se dando da primeira para a segunda forma social:

Contatos versus relações (o homem é um ser de relações e não só de contatos);

Estar no mundo versus estar com o mundo (o homem não apenas está no mundo, mas com o mundo, o que implica sua abertura à realidade);

Domesticação versus libertação;

Viver versus existir;

Acomodação, ajustamento, adaptação versus integração;

Fechado versus aberto (a sociedade brasileira se encontrava em trânsito da condição de fechada para aberta);

Rígido versus plástico;

Reflexo versus reflexivo;

Funções instintivas e emocionais versus funções intelectuais;

Gregário versus cooperativo;

Rinocerôntico versus parentético (alusão à peça de Ionesco, "Os rinocerontes", por meio de Guerreiro Ramos);

Imerso versus emerso;

Mudança versus trânsito (se todo trânsito é mudança, nem toda mudança é trânsito);

Sociedade fechada versus sociedade em trânsito;

Sociedade em trânsito versus sociedade aberta;

Acomodado, domesticado versus criticizado;

Estar no trânsito versus ser do trânsito (estar no trânsito, sem ser dele versus estar nele, sendo dele);

Elite superposta versus elite integrada;

Sociedade heterogeneamente aberta versus sociedade homogeneamente aberta;

Esmagar (o oponente) versus convencer, converter;

Sectário versus radical;

Massa versus povo;

Otimismo ingênuo (idealista) versus otimismo crítico;

Autodesvalia versus autoconfiança; 


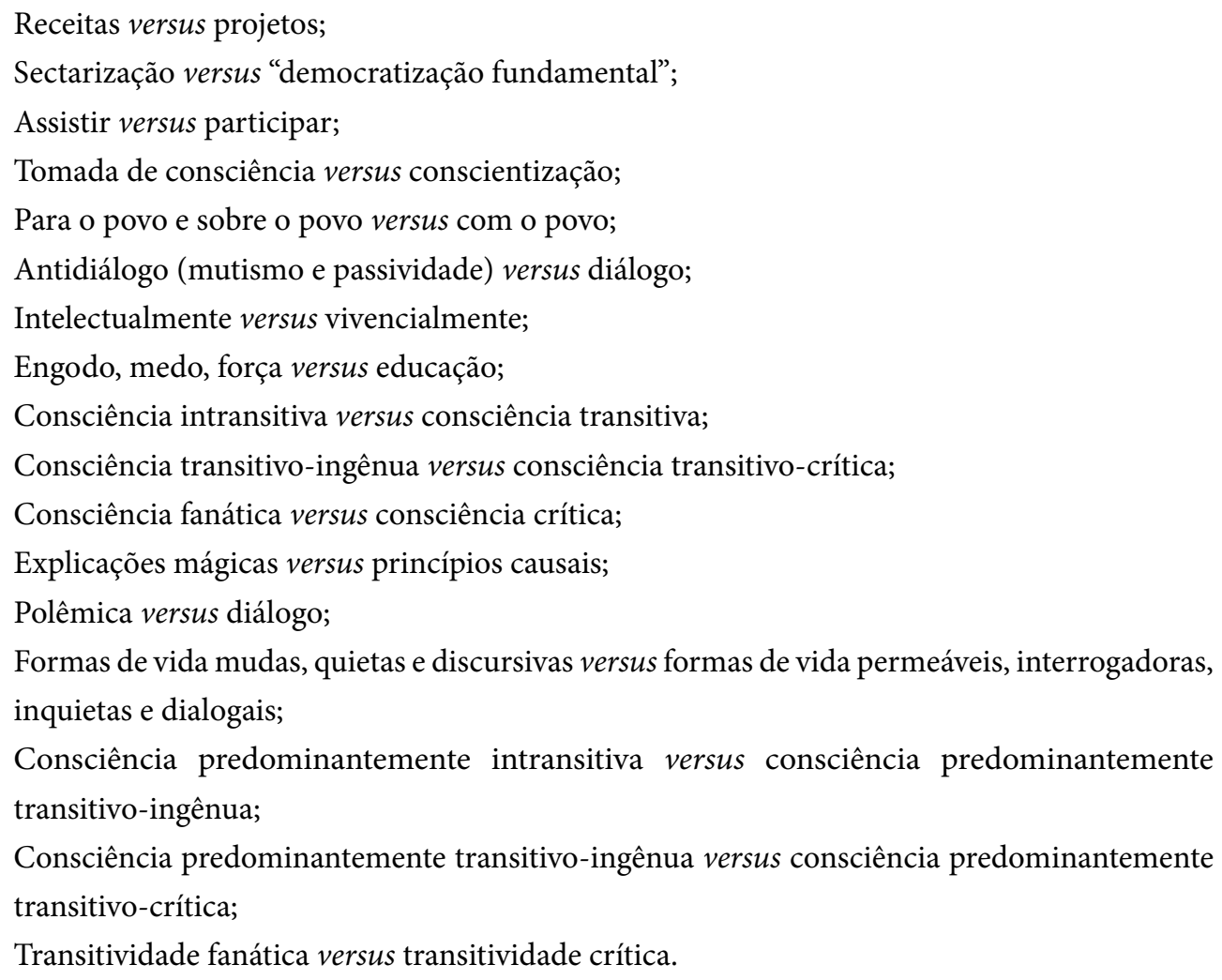

Vê-se que Paulo Freire entendia a pessoa humana como um ser de relações que se afirmava como sujeito de sua existência, construída historicamente em comunhão com os outros homens, o que o definia como um ser dialogal e crítico. Todavia, essa "vocação ontológica de ser sujeito" esbarrava numa realidade social que a contradizia, já que às forças dominantes interessava manter a maioria dos homens em situação de alienação e dominação.

À luz dessa concepção, Paulo Freire interpretava que a sociedade brasileira dos anos 1960 passava por um processo de trânsito de uma sociedade fechada para uma aberta. No interior desse processo, o autor situava o dilema da educação: estar a serviço da alienação e da domesticação ou da conscientização e da libertação. Para Paulo Freire, a educação surgia como um instrumento de crucial importância para promover a passagem da consciência popular do nível transitivo-ingênuo para o nível transitivo-crítico, evitando-se a sua queda na consciência fanática. Tratava-se, pois, de uma educação conscientizadora, emergindo o neologismo "conscientização", cuja criação por vezes se atribuiu ao próprio Paulo Freire. No entanto, ele apresenta o seguinte esclarecimento:

Acredita-se geralmente que sou autor deste estranho vocábulo "conscientização" por ser este o conceito central de minhas ideias sobre a educação. Na realidade, foi criado por uma equipe de professores do INSTITUTO SUPERIOR DE ESTUDOS BRASILEIROS por volta de 1964. Pode-se citar entre eles o filósofo Álvaro Vieira Pinto e o professor Guerreiro. Ao ouvir pela primeira vez a palavra conscientização, percebi imediatamente a profundidade de seu significado, porque estou absolutamente convencido de que a educação, como prática da liberdade, é um ato de conhecimento, uma aproximação crítica da realidade.

Desde então, esta palavra forma parte de meu vocabulário. Mas foi Hélder Câmara quem se encarregou de difundi-la e traduzi-la para o inglês e para o francês (FREIRE, 1980, p. 25). 
Entretanto, em uma entrevista concedida em 1990 e publicada no livro A educação na cidade, Carlos Alberto Torres perguntou a Freire o que significava a palavra "conscientização" e por que ele deixou de usá-la, ao que Paulo Freire respondeu:

Você me indaga sobre o ter deixado de fazer referências diretas à palavra conscientização. É verdade. A última vez em que me estendi sobre o tema foi em 1974 - já fazia quatro anos, mais ou menos, que eu não a usava - num seminário no Conselho Mundial de Igrejas, em Genebra, com Ivan Illich, em que ele retomou o conceito de "desescolarização" e eu o de conscientização.

Naturalmente, contudo, ao não usar a palavra, não recusei sua significação. Como educador, portanto como político, estive sempre envolvido com a compreensão mais profunda do conceito, nas minhas atividades prático-teóricas.

Tive, indiscutivelmente, razões para desusar a palavra. Nos anos 70, com exceções, é claro, falava-se ou se escrevia de conscientização como se fosse ela uma pílula mágica a ser aplicada em doses diferentes com vistas à mudança do mundo. Mil pílulas para um patrão reacionário. Dez, para um líder sindical autoritário. Cinquenta pílulas para um intelectual cuja prática contradiz o discurso etc. etc.

Me pareceu àquela época, e sobre isso conversei com Elza, que, de um lado, eu deveria de uma vez deixar de usar a palavra, de outro, procurar, em entrevistas, em seminários, em ensaios - o que fiz realmente - aclarar melhor o que pretendia com o processo conscientizador, no sentido de diminuir os riscos abertos às interpretações idealistas, tão funestas quanto as objetivistas mecanicistas (FREIRE, 1991, p. 113-114).

Passado esse período, em que deixou de fazer uso da palavra "conscientização", diante da persistência dos obstáculos colocados pelas "condições materiais, econômicas, sociais e políticas, culturais e ideológicas" para a realização da tarefa histórica de mudar o mundo, Paulo Freire decidiu voltar a usar o termo "conscientização", como podemos ler na passagem a seguir, de Pedagogia da autonomia, último livro por ele publicado, em 1996, um ano antes de falecer:

Nos anos 60, preocupado já com esses obstáculos, apelei para a conscientização não como panaceia, mas como um esforço de conhecimento crítico dos obstáculos, vale dizer, de suas razões de ser. Contra toda a força do discurso fatalista neoliberal, pragmático e reacionário, insisto hoje, sem desvios idealistas, na necessidade da conscientização. Insisto na sua atualização. Na verdade, enquanto aprofundamento da "prise de conscience" [em francês no original] do mundo, dos fatos, dos acontecimentos, a conscientização é exigência humana, é um dos caminhos para a posta em prática da curiosidade epistemológica. Em lugar de estranha, a conscientização é natural ao ser que, inacabado, se sabe inacabado. A questão substantiva não está por isso no puro inacabamento ou na pura inconclusão. A inconclusão, repito, faz parte da natureza do fenômeno vital (FREIRE, 2007, p. 54-55).

Tendo em vista o objetivo de conscientizar a população, evitando a queda do nível da consciência transitivoingênua para a consciência fanática e possibilitando sua passagem para a consciência transitivo-crítica, é que foi criado o método de alfabetização

Com base na "teoria do trânsito", objeto do primeiro capítulo, o livro Educação como prática da liberdade aborda, no segundo capítulo - denominado "Sociedade fechada e inexperiência democrática” -, a situação brasileira, 
mostrando as raízes de nossa inexperiência democrática, raízes essas localizadas na forma como ocorreu a colonização do Brasil.

No terceiro capítulo, "Educação versus massificação", foi feita a crítica da educação dominante, definida como marcada pelo "gosto da palavra oca", de caráter bacharelesco (FREIRE, 1974, p. 93), assistencializadora, que, em lugar de comunicar, apenas faz comunicados. Para evitar o risco da massificação, Freire postulou uma educação voltada para a passagem da transitividade ingênua à transitividade crítica: "uma educação para a decisão, para a responsabilidade social e política" (FREIRE, 1974, p. 88), "que possibilitasse ao homem a discussão corajosa de sua problemática" (FREIRE, 1974, p. 89).

Finalmente, no quarto capítulo, "Educação e conscientização", a partir das experiências realizadas no Movimento de Cultura Popular e no Serviço de Extensão Cultural da Universidade do Recife, Freire descreveu seu método de alfabetização, evidenciando sua matriz pedagógica, suas fases e execução prática.

A matriz pedagógica traduziu-se como um "método ativo, dialogal, crítico e criticizador", que propiciasse a "modificação do conteúdo programático da educação" com base "no uso de técnicas como a da Redução e da Codificação" (FREIRE, 1974, p. 107).

A elaboração e a execução do método comportavam cinco fases, que iam do levantamento do universo vocabular dos grupos com quem se ia trabalhar (primeira fase); passando pela escolha das palavras a partir do universo vocabular pesquisado (segunda fase); pela criação de situações existenciais próprias do grupo com o qual se iria trabalhar (terceira fase); pela elaboração de fichas-roteiro para auxiliar o trabalho dos coordenadores de debate (quarta fase); até a quinta fase, que consistia na feitura das fichas com a decomposição das famílias fonêmicas correspondentes aos vocábulos geradores (FREIRE, 1974, p. 112-115).

Tratava-se de um trabalho de educação popular que não disfarçava certa rejeição da forma como o ensino se desenvolvia na educação escolar. Com efeito, para a execução do método, Paulo Freire idealizou os círculos de cultura, em lugar de escola; nesses círculos, atuariam os coordenadores de debates, em lugar dos professores; tais coordenadores, por sua vez, em lugar de aula discursiva, exercitariam o diálogo com os participantes do grupo; os participantes ativos do grupo constituíam substitutos dos alunos, com sua tradição de passividade; em lugar dos pontos e programas alienados que os professores normalmente trabalham com seus alunos, os coordenadores de grupo trabalhariam com os participantes do grupo uma "programação compacta, reduzida e codificada em unidades de aprendizado" (FREIRE, 1974, p. 103).

No livro História das ideias pedagógicas no Brasil, sintetizei assim o trabalho dos círculos de cultura:

O trabalho pedagógico nos círculos de cultura se iniciava pela projeção, com o uso de slides ou cartazes, da situação contendo a primeira palavra geradora. Após amplo debate sobre as várias implicações da situação analisada, chegava-se, mediante o processo de decodificação propiciada pela análise, à visualização da palavra geradora. Esta, projetada em novos slides ou cartazes, aparecia, primeiro, isolada do objeto, mas por inteiro; depois, separada em sílabas e, daí, às famílias fonêmicas, cuja ficha foi designada de "ficha da descoberta". Para ilustrar o procedimento, o autor lançou mão da palavra "tijolo". No primeiro passo, essa palavra era apresentada numa situação do trabalho em construção. Discutida essa situação, visualizava-se a palavra, que depois era apresentada sem o objeto: Tijolo. Numa nova projeção, ela aparecia desmembrada em suas sílabas: ti-jo-lo. Daí se chegava às famílias fonêmicas: ta-te-ti-to-tu; ja-je-ji-jo-ju; la-le-li-lo-lu. Finalmente, apresentava-se a projeção da "ficha da descoberta" contendo as três famílias fonêmicas em conjunto:

ta-te-ti-to-tu;

ja-je-ji-jo-ju;

la-le-li-lo-lu (SAVIANI, 2021, p. 325-326). 
Diante dessa ficha, os participantes do grupo iam fazendo leituras em horizontal, em vertical, em diagonal, a partir dos vários pontos possíveis, identificando e formando palavras como: "tatu, luta, tijolo, lajota, tito, loja, jato, juta, lote, lula, tela”; e podiam chegar a extrapolar as combinações silábicas dadas, com resultado não previsto: por exemplo, tirando o $i$ de $l i$, juntando-o ao le e somando ao te: leite (SAVIANI, 2021, p. 118). Podiam até chegar à construção de frases, como ocorreu com um analfabeto de Brasília, que, diante da ficha da descoberta montada sobre a palavra tijolo, proferiu este enunciado: "tu já lê" (SAVIANI, 2021, p. 118).

A partir da ficha da descoberta, os alfabetizandos iam identificando vocábulos pela combinação de fonemas conhecidos, dando sequência ao processo de alfabetização.

Dando um indicativo de que se pretendia, no fundo, substituir todo o sistema escolar por essa espécie de "pedagogia dos círculos de cultura", ao término do livro, Paulo Freire registrou que a ideia, obviamente, era não se satisfazer com a mera alfabetização. Por isso, já se pensava nas etapas seguintes a serem desenvolvidas segundo o mesmo espírito estruturante de uma "pedagogia da Comunicação".

O livro se completou com um apêndice contendo, ilustradas por gravuras, as dez situações motivadoras com que se iniciava o processo de alfabetização nos círculos de cultura e as dezessete palavras geradoras definidas a partir de pesquisa do "universo vocabular" no estado do Rio de Janeiro.

As referências bibliográficas em que se apoiou a construção de Educação como prática da liberdade indicam que, pelo aspecto filosófico, a orientação adotada é toda ela lastreada no existencialismo e no personalismo cristãos. Daí o apoio nas obras de Karl Jaspers, Erich Fromm, Hans Freyer, Tristão de Ataíde (Alceu de Amoroso Lima), Papa João XXIII, Simone Weil, Gabriel Marcel, Jacques Maritain e Emmanuel Mounier. Pelos aspectos histórico-cultural e sócio-político, a referência teórica é encontrada nos chamados "intérpretes do Brasil", em especial os intelectuais do Instituto Superior de Estudos Brasileiros (ISEB), com apoio nos isebianos históricos, Guerreiro Ramos e Álvaro Vieira Pinto, que se somaram aos já citados em "Educação e atualidade brasileira": Roland Corbisier, Hélio Jaguaribe e Nelson Werneck Sodré. Entre os "intérpretes do Brasil” não integrantes do ISEB, são citados: Celso Furtado, Fernando de Azevedo, Caio Prado Júnior, Viana Moog, Rugendas, Oliveira Viana, Gilberto Freyre, Antonil, além de Anísio Teixeira, que integrou o Conselho Curador do ISEB.

Essa plêiade de autores, que somam 33 trabalhos citados, respalda a conclusão de Vanilda Pereira Paiva, a qual situa Paulo Freire no campo ideológico do nacionalismo-desenvolvimentista. No entanto, os anos de permanência no Chile determinaram uma alteração nesse perfil ideológico.

\section{Aos Esfarrapados do Mundo}

Após a conclusão de Educação como prática da liberdade, Paulo Freire se dedicou imediatamente à redação de Pedagogia do oprimido, considerada sua obra mais importante, cujo manuscrito, concluído em 1968, abre-se com a seguinte dedicatória: "Aos esfarrapados do mundo e aos que neles se descobrem e, assim descobrindo-se, com eles sofrem, mas, sobretudo, com eles lutam." Uma peculiaridade dessa obra é que foi publicada primeiro em inglês, nos Estados Unidos, tendo sido lançada, em seguida, no Brasil, em português, e no Uruguai e na Argentina, em espanhol. As edições brasileira e argentina contaram com prefácio de Ernani Maria Fiori, denominado "Aprender a dizer sua palavra: o método de alfabetização do professor Paulo Freire”. Fiori, dotado de sólida formação filosófica baseada na fenomenologia existencial, insere-se no pensamento social dos católicos franceses. Com esse cabedal filosófico, Fiori aborda o método de Paulo Freire, reconstituindo suas características, explicitando seus fundamentos filosófico-existenciais c considerando que não foi por acaso que o método de Freire, como método de conscientização, tenha surgido 
como método de alfabetização. Isso porque a cultura letrada se manifesta como reflexão da cultura sobre si mesma, marcando "a aparição do homem no longo processo da evolução cósmica", em que a essência humana se existencializa e se descobre como história. Ao tomar consciência de sua historicidade, o homem se volta reflexivamente sobre si mesmo e "passa a dizer-se", a tornar-se "consciência historiadora", sendo "levado a escrever sua história". Daí a importância do alfabetizar-se, que consiste no aprender a ler a palavra escrita na qual a cultura se expressa e, assumindo-a criticamente, já não é mera repetição do passado, mas "anúncio e promessa do que há de vir. O destino, criticamente, recupera-se como projeto" (FIORI apud FREIRE, 2005, p. 18-19). Assim, conclui Fiori que a alfabetização é toda a pedagogia: "aprender a ler é aprender a dizer sua palavra. E a palavra humana imita a palavra divina: é criadora" (FIORI apud FREIRE, 2005, p. 21).

Metodologicamente, a construção da obra Pedagogia do oprimido está em consonância com a forma como foi organizado o livro anterior, Educação como prática da liberdade, operando, também, por meio de pares antitéticos: opressor versus oprimido; educação bancária versus educação problematizadora; antidialogicidade versus dialogicidade

O livro foi estruturado em quatro capítulos sem títulos. Na apresentação da edição fac-símile dos manuscritos, de 2013, lemos:

Nos originais, não foram encontrados, nem o título do livro, nem títulos de seus quatro capítulos, coincidindo com o que aconteceu com as edições brasileiras até a 17a edição (1987), revista pelo próprio Freire. Nelas, só apareciam, no início de cada um de seus capítulos, os temas destacados por ele. No capítulo três, só aparecia o numeral romano "III" (FREIRE, 2013, p. 04-05).

Observa-se, então, que, nas edições impressas, cada capítulo tem, na página inicial, um breve sumário, indicando o conteúdo correspondente. O primeiro capítulo traz um sumário com quatro tópicos e um aforismo. Os quatro tópicos indicam o conteúdo tratado no capítulo: 1. Justificação da pedagogia do oprimido; 2. A contradição opressores-oprimidos, sua superação; 3. A situação concreta de opressão e os opressores; 4. A situação concreta de opressão e os oprimidos. O aforismo indica o sentido nuclear e geral do conteúdo do capítulo: ninguém liberta ninguém, ninguém se liberta sozinho - os homens se libertam em comunhão. No livro História das ideias pedagógicas no Brasil (SAVIANI, 2021, p. 330-331), resumi o conteúdo do livro Pedagogia do oprimido conforme indico nos próximos três parágrafos:

Se o capítulo I se empenha em caracterizar a situação de opressão como característica humanosocial que extrapola a questão especificamente educacional, o capítulo II irá se debruçar sobre a questão pedagógica propriamente dita. Daí o sumário desse capítulo, com quatro tópicos e dois aforismos: 1 . A concepção "bancária" da educação como instrumento de opressão, seus supostos, sua crítica; 2 . A concepção problematizadora da educação e a libertação, seus supostos; 3. A concepção "bancária" e a contradição educador-educando; 4 . A concepção problematizadora e a superação da contradição educador-educando. Os dois aforismos sintetizam o conteúdo do capítulo: 1 . Ninguém educa ninguém - ninguém se educa a si mesmo - os homens se educam entre si mediatizados pelo mundo; 2. O homem como ser inconcluso e consciente de sua inconclusão e seu permanente movimento em busca de ser mais.

O capítulo III será dedicado à exposição da pedagogia do oprimido como pedagogia dialógica. Eis seu sumário: 1. A dialogicidade: essência da educação como prática da liberdade; 2. Dialogicidade e diálogo; 3. O diálogo começa na busca do conteúdo programático; 4. As relações homem-mundo, os "temas geradores" e o conteúdo programático da educação; 5. A investigação dos temas geradores e sua metodologia; 6. A significação conscientizadora da investigação dos temas geradores; 7. Os momentos da investigação. 
Por fim, o quarto capítulo irá contrapor as teorias da ação antidialógica e dialógica, de acordo com o seguinte roteiro: 1. A antidialogicidade e a dialogicidade como matrizes de teorias de ação cultural antagônicas: a primeira serve à opressão e a segunda, à libertação; 2. A teoria da ação antidialógica e suas características: conquista, divisão, manipulação, invasão cultural; 3. A teoria da ação dialógica e suas características: colaboração, união, organização, síntese cultural.

Diferentemente do que ocorreu nas obras anteriores, em Pedagogia do oprimido, Freire dialoga com a filosofia dialética e com o marxismo, citando, em profusão, tanto autores da própria matriz dessa corrente filosófica quanto interpretações a ela ligadas. Assim, além da Fenomenologia do espírito, de Hegel; de Ideias: introdução geral a uma fenomenologia pura, de Husserl; de Eu e tu, de Martin Buber; e de Testemunha cristã, de Chenu, Freire se reporta a Marx, Engels, Rosa Luxemburgo, Lukács, Marcuse, Fanon, Memmi, Debray, Simone de Beauvoir, Sartre, Che Guevara, Mao Tse-Tung, Kosik, Lucien Goldman, André Nicolai, Lênin, Fidel Castro, Petrovic, Althusser, Gruzman, Erich Fromm, Osborn, Dufrenne, Gerassi, André Maine.

Vê-se que, em Pedagogia do oprimido, os autores que integram, de algum modo, a tradição marxista constituem maioria. Além de Marx, Engels e Lênin, temos Rosa Luxemburgo, Lukács, Mao Tse-Tung, Lucien Goldman, Althusser, Kosik, Marcuse, Debret, Guevara, Fidel Castro, Sartre. O que explicaria essa diferença da fase chilena em relação à fase brasileira? Antes de ensaiar uma resposta a essa pergunta, cumpre assinalar que isso não significa que Paulo Freire tenha aderido ao marxismo ou mesmo que tenha incorporado em sua visão teórica da questão pedagógica a perspectiva do marxismo. Na verdade, é possível reconhecer a matriz hegeliana em sua análise da relação opressor-oprimido, calcada na dialética do senhor e do escravo que Hegel explicita na Fenomenologia do espírito. Quanto aos autores marxistas, eles são citados incidentalmente, apenas para reforçar aspectos da explanação levada a efeito por Freire, sem nenhum compromisso com a sua perspectiva teórica. Como explicitei em História das ideias pedagógicas no Brasil (SAVIANI, 2021, p. 332-333), a eventual apropriação de algum conceito ocorre pelo deslocamento da concepção de origem, o que pode ser ilustrado com o conceito de limite máximo de consciência possível, de Lucien Goldman. Em Goldman, esse conceito é de matriz lukacsiana e pressupõe não apenas a distinção entre consciência real e consciência possível, mas também o antagonismo entre as classes fundamentais, dominante e dominada, sob o capitalismo; isto é, a burguesia e o proletariado. O conceito supõe, portanto, a luta de classes. Assim, raciocina Goldman, se a burguesia pode, em certas circunstâncias, ser dotada de uma consciência real mais avançada do que o proletariado, em termos de consciência possível, em virtude das posições respectivamente ocupadas por essas duas classes no sistema de produção, a burguesia estará necessariamente aquém do proletariado. Dessa maneira, o limite máximo de consciência possível, nas condições em que vigora o modo de produção capitalista, só poderá ser atingido pelo proletariado (GOLDMANN, 1976, p. 94-103). Contudo, não é esse o contexto em que Freire lança mão do conceito supracitado. Ele se reporta a Goldman quando está tratando da investigação da "situação-limite". Considera que essa, como realidade concreta, "pode provocar em indivíduos de áreas diferentes, e até de subáreas de uma mesma área, temas e tarefas opostos que exigem, portanto, diversificação programática para o seu desvelamento" (FREIRE, 2005, p. 124). Freire retira daí a conclusão de que os investigadores devem "centrar-se no conhecimento do que Goldman chama 'consciência real' (efetiva) e 'consciência máxima possível”', introduzindo, como sinônimo, o conceito de inédito viável: "Daí que, ao nível da consciência real, os homens se encontrem limitados na possibilidade de perceber mais além das situações-limites, o que chamamos de inédito viável” (FREIRE, 2005, p. 124).

Em resumo, embora citando grande número de autores marxistas, a concepção de fundo que rege a elaboração da Pedagogia do oprimido permanece sendo a filosofia personalista na versão política do solidarismo cristão. Eis que, já nas primeiras páginas do primeiro capítulo, quando está caracterizando a relação opressor-oprimido com base na dialética do senhor e do escravo, de Hegel, Freire estabelece a condição 
para que o opressor possa se solidarizar verdadeiramente com os oprimidos: "o opressor só se solidariza com os oprimidos quando seu gesto deixa de ser um gesto piegas e sentimental, de caráter individual, e passa a ser um ato de amor àqueles" (FREIRE, 2005, p. 40). Eis aí a crença cristã de que o opressor possa vir a amar o oprimido! Efetivamente, na dialética do senhor e do escravo, de Hegel, a libertação do escravo ocorre abstratamente, no âmbito do conceito. Com efeito, o escravo, passando a servir ao senhor por sua própria vontade, liberta-se da escravidão e, ao libertar-se, liberta também o senhor, que já não precisa coagir o escravo a servi-lo, pois esse já o serve de livre e espontânea vontade. Assim, a libertação ocorre no âmbito da ideia, da consciência, do conceito; na vida real, de fato, mantém-se a escravidão.

O solidarismo cristão, na versão decorrente da doutrina social da Igreja expressa nas encíclicas papais, foi divulgado no Brasil pelo padre Fernando Bastos de Ávila, primeiro por meio das obras Neocapitalismo, socialismo, solidarismo (ÁVILA, 1963) e Solidarismo (ÁVILA, 1965), ambos os livros publicados pela Editora AGIR, do Rio de Janeiro. Todavia, em Paulo Freire, o solidarismo assume as conotações próprias do radicalismo católico que desembocou na corrente denominada "teologia da libertação". Poderíamos mesmo considerar que a pedagogia libertadora de Freire é o correlato, em educação, da teologia da libertação.

Tentemos, então, uma resposta à pergunta referente à diferença entre a fase brasileira, na qual a produção teórica marxista encontra-se inteiramente ausente das formulações de Freire, e a fase chilena, em que são abundantes as citações de autores marxistas.

No Brasil, Paulo Freire integrou o MCP, Movimento de Cultura Popular, sendo uma de suas principais lideranças. Esse foi um movimento de orientação católica cujos militantes eram dominantemente integrantes da Ação Católica, compreendendo a JAC, Juventude Agrária Católica; a JEC, Juventude Estudantil Católica - que aglutinava os estudantes secundaristas; a JOC, Juventude Operária Católica; e, principalmente, a JUC, Juventude Universitária Católica. O MCP se contrapunha aos CPC, Centros Populares de Cultura, de orientação marxista, disputando com eles a primazia da influência sobre as massas populares. No Chile, Paulo Freire se encontrou numa situação diferenciada, caracterizada pela ação conjunta da Democracia Cristã, especialmente de sua ala esquerda, com partidos e movimentos de orientação marxista. Além disso, a palavra de ordem do engajamento político dos católicos, que já vinha sendo alimentado pelo Concílio Vaticano II, veio a receber impulso na II Conferência-Geral do Episcopado Latino-Americano, realizada em Medellín (Colômbia) de 26 de agosto a 4 de setembro de 1968. Nessa conferência, prevaleceu a orientação que se tornou conhecida como "teologia da libertação" e que foi ratificada pela III Conferência Episcopal Latino-americana, realizada em Puebla, no México, em 1979. Ora, a teologia da libertação se caracteriza exatamente por diferenciar o materialismo dialético do materialismo histórico. $\mathrm{O}$ dialético é entendido como doutrina e, nessa condição, é incompatível com a doutrina da Igreja, devendo, pois, ser rejeitado. Já o histórico é compreendido como ciência que busca explicar objetivamente como se deu e vem se dando o desenvolvimento histórico da humanidade. Assim, não só pode como deve ser levado em conta, pois seria a partir desse conhecimento que poderíamos compreender os problemas, os conflitos e as lutas que vêm vitimando os seres humanos e, com base nessa compreensão, deveríamos agir para superar essa situação. Ou seja, a "opção preferencial pelos pobres", palavra de ordem central da teologia da libertação, só será viável com o conhecimento da realidade da opressão que vitima os “esfarrapados do mundo". Esse conhecimento é, em boa parte, provido pelo materialismo histórico. Eis porque Paulo Freire, em diálogo do qual participei juntamente com ele e Adriano Nogueira - quando formulei a pergunta "Como refletiremos criticamente sobre o atual capitalismo tendo em vista condições de vida social que superem os problemas atuais?” -, deu uma resposta da qual destaco dois momentos. O primeiro, quando ele disse: "Perguntaram-me, recentemente, num debate: Paulo, tu te definirias como sendo marxista? E eu comentava: Eu lhes digo que, por respeito a Marx, eu não me defino marxista” (FREIRE apud SAVIANI, 2010, p. 9); e o segundo, em que ele afirmou: 
Uma de minhas cobranças a nós, de esquerda, é um movimento de retornar a Marx. Estudá-lo, buscando adivinhar aquilo que Marx não pôde ter visto. É uma certa petulância, eu sei. Para adivinhar o que e como Marx veria, hoje, o que não pôde ter visto é necessário assumi-lo. Em parte, ao menos. E sem diviniza-lo, claro (FREIRE apud SAVIANI, 2010, p. 10).

Concomitantemente à finalização de Pedagogia do oprimido, Paulo Freire concluía outros trabalhos, dominantemente ligados à questão rural, dada a sua vinculação, em Santiago do Chile, com o Instituto de Pesquisa e Treinamento em Reforma Agrária (ICIRA). Desse vínculo, resultaram publicações como Educação e conscientização: extensionismo rural, de 1968; Contribuição ao processo de conscientização do homem na América Latina, também de 1968; e Extensão ou comunicação? A conscientização no meio rural, de 1969. Data também dessa época Ação cultural para a liberdade, livro que, em diversos registros da produção bibliográfica de Freire, é dado como publicado em 1968 pelo ICIRA. Entretanto, na publicação brasileira, de 1976, Paulo Freire fez constar a seguinte nota: "escrito em fins de 1969, em Cambridge, Estados Unidos, este trabalho foi publicado, pela primeira vez, por Harvard Educational Review, em 1970" (FREIRE, 1976, p. 42).

Chamou-me a atenção, nesse texto, a distinção entre ação cultural e revolução cultural, entendendo-se a primeira como a que precede a transformação estrutural da sociedade; e a segunda como aquela que a sucede: “a ação cultural para a libertação se realiza em oposição às classes dominantes, enquanto a revolução cultural se faz com a revolução já no poder" (FREIRE, 1976, p. 84). Ao que parece, essa análise revela certa simpatia de Paulo Freire pelo maoísmo. De fato, encontrava-se, então, em pleno desenvolvimento a revolução cultural chinesa, desencadeada por Mao Tse-Tung em 1966 e que se estendeu até 1976. Na publicação argentina, cuja primeira edição data de janeiro de 1975, há, na última página, a seguinte nota: "Ainda que estas afirmações sobre a revolução cultural se possam aplicar a uma análise da revolução cultural chinesa, esse não é nosso propósito. Limitamos nosso estudo a um esboço da relação entre a revolução cultural e a ação cultural, que propomos" (FREIRE, 1975, p. 99). Essa nota não aparece na edição brasileira. Com o chamado "maio de 1968", movimento de rebeldia dos estudantes universitários, aliado à repressão da "primavera de Praga" pela União Soviética, grande número de intelectuais de esquerda, antes simpatizantes da linha ideológica russa, aderiram ao maoísmo.

De fato, a influência do maoísmo, versão do marxismo na experiência chinesa, foi muito forte em contraposição à versão russa do marxismo, que trazia a marca do stalinismo, denunciado por Khruschev no XX Congresso do Partido Comunista da União Soviética, realizado em fevereiro de 1956. Além disso, podem ser citados fatos de grande repercussão, como a repressão à Hungria, em novembro de 1956, e a invasão da Tchecoslováquia, inviabilizando a "primavera de Praga", em agosto de 1968, ano em que havia eclodido a rebelião estudantil. Nesse cenário, os intelectuais de esquerda tendiam a ser dominantemente críticos em relação à versão russa do marxismo e do socialismo. Enquanto isso, a experiência chinesa - a China entrou em dissidência com a União Soviética - passou a ser uma referência nessas análises críticas. O próprio Sartre fez militância de esquerda numa linha próxima dos chamados grupos "gauches", de orientação maoísta, polemizando com o Partido Comunista Francês, então alinhado à União Soviética.

Nesse contexto, emergiram as teorias que chamei de crítico-reprodutivistas, entre as quais a teoria da escola dualista exposta no livro de Baudelot e Establet, A escola capitalista na França, publicado em 1971. Esses autores, que se situam no interior do marxismo, formaram-se sob a influência de Althusser, mas romperam com ele e passaram a desenvolver uma teoria articulada com o maoísmo. Empenharam-se em fazer um trabalho centrado na teoria da contradição, numa análise sustentada teoricamente no marxismo. $\mathrm{O}$ resultado foi mais uma crítica contundente ao caráter reprodutivista do aparelho escolar. Mantiveram a ideia de Althusser de que a escola é um aparelho ideológico de Estado e tentaram mostrar a sua função. Procuraram explicitar aquilo que, em Althusser, aparecia apenas como uma ideia diretriz, e o fizeram a partir de uma análise detalhada dos dados estatísticos relativos ao sistema de ensino 
francês. Foi por esse caminho que eles chegaram ao entendimento de que o sistema de ensino é constituído por apenas duas redes: a rede SS (secundária-superior) e a rede PP (primária-profissional), não havendo a possibilidade de uma terceira rede. Essas duas redes articulam-se no objetivo comum de realizar a inculcação ideológica e a reprodução das relações sociais de produção. Os autores admitem a existência da ideologia do proletariado, que, no entanto, tem origem e se situa fora da escola, nas massas operárias e em suas organizações. A escola é entendida como um aparelho ideológico da burguesia em sua luta contra o proletariado, tendo por missão impedir o desenvolvimento da ideologia desse último e a luta revolucionária. De certo modo, Paulo Freire compartilhava dessa visão, destacando a precedência da educação popular, entendida como uma educação do povo, pelo povo e para o povo, em contraste com a educação escolar, entendida como uma educação da elite, pela elite e para a elite, no caso da rede secundáriasuperior; e da elite, pela elite e para o povo, no caso da rede primária-profissional,

Paulo Freire permaneceu no Chile até o final da década de 1960 e, após passar um curto período nos Estados Unidos, em 1969, a convite da Universidade de Harvard, transferiu-se, em 1970, para a Suíça, onde permaneceu como consultor especial do Conselho Mundial das Igrejas, em Genebra, até seu retorno ao Brasil, em 1980. Esse Conselho constitui grande expressão do movimento ecumênico, que congrega centenas de denominações religiosas cristãs. $\mathrm{O}$ vínculo de Paulo Freire com o Conselho Mundial das Igrejas possibilitou-lhe prestar assessoria educacional a diversos países, em especial aqueles da África que se encontravam em processo de descolonização, dando origem a diversas publicações, entre as quais se destaca Cartas à Guiné-Bissau: registros de uma experiência em processo (FREIRE, 1977).

\section{Conclusão}

Eis como - diferentemente do que se acredita e a que, por vezes, alguma fala de Freire deu respaldo - Paulo Freire não se constituiu como educador atuando praticamente, tendo desenvolvido sua teoria a posteriori, a partir da prática de alfabetização realizada anteriormente. Na verdade, a prática inaugurada com as sempre lembradas “40 horas de Angicos” ocorreu em 1963, tendo, portanto, por base a elaboração teórica explicitada na tese de concurso Educação e atualidade brasileira, que data de 1959. O êxito da experiência de Angicos entusiasmou o Presidente João Goulart e sua equipe de governo envolvida com o programa das Reformas de Base, entre as quais se encontrava a reforma da educação. Em consequência, o Ministro da Educação, Paulo de Tarso, convidou Paulo Freire para presidir a Comissão Especial coordenadora do Programa Nacional de Alfabetização, instituído pelo Decreto n. 53.465, de 21 de janeiro de 1964. Como afirma Ana Maria Araújo Freire, nasceu, assim, o Programa que, "pelo 'Método Paulo Freire' tencionava alfabetizar politizando cinco milhões de adultos". Ana Maria Freire continua, observando que esses adultos passariam a "fazer parte conscientemente do até então restrito colégio eleitoral brasileiro, do início dos anos 60", já que a lei vigente à época exigia que os eleitores fossem alfabetizados. A autora conclui: "Para se ter uma ideia da extensão desse Programa, basta lembrar que tinham votado na eleição presidencial da qual saíram vencedores o Sr. Jânio da Silva Quadros e João Belchior Goulart apenas pouco mais de onze milhões e seiscentos mil eleitores" (FREIRE, 2006, p. 145). Era, pois, um colégio eleitoral muito pequeno, considerando que a população do país, em 1960, ultrapassava 72 milhões de habitantes. No entanto, se fosse executado o Programa, no prazo de um ano a quantidade de eleitores praticamente seria acrescida de quase metade do número então existente. No entanto, não se tratava apenas de aumentar o número de eleitores. Pelo método de alfabetização adotado no referido Programa Nacional de Alfabetização, o eleitorado brasileiro seria ampliado com a entrada de novos membros que não somente estavam legalmente aptos a votar. Os novos eleitores seriam oriundos das camadas populares que, ao serem alfabetizadas, tornavam-se conscientes da opressão a que estavam submetidas, sendo desafiadas a lutar para transformar o estado de coisas então vigente. Por isso, as classes dominantes, que se posicionavam contra as Reformas de Base, também rejeitavam tal política de alfabetização. Eis por que o golpe militar, 
consumado em $1^{\circ}$ de abril de 1964, tratou logo de abortar essa iniciativa, baixando, em 14 de abril, o Decreto n. 53.886, que tinha a seguinte ementa: "Revoga o Decreto n. 53.465, de 21 de janeiro de 1964, que instituiu o Programa Nacional de Alfabetização do Ministério da Educação e Cultura."

Diante do fechamento político, Paulo Freire partiu para o exílio, ficando o Brasil privado de sua importante contribuição. Podemos conjecturar que, sem o golpe, teríamos o avanço das Reformas de Base, com a efetivação do Programa Nacional de Alfabetização. Logo, Paulo Freire teria se integrado ao nosso movimento educativo, indo muito além do plano de alfabetização e exercendo, com certeza, influxo também sobre as redes públicas de educação escolar. Como resultado do golpe militar, não apenas sua obra deixou de impactar diretamente a educação brasileira, como também, embora tendo sua importância reconhecida mundialmente, acabou dispersa, não chegando a exercer influxo direto na organização e no desenvolvimento de nenhum dos países em que se difundiu.

Agora, neste ano de 2021, em que comemoramos o centésimo ano do nascimento de Paulo Freire, encontramo-nos numa situação semelhante àquela que se iniciou com o golpe de 1964. Com efeito, vivemos agora o período pós-golpe de 2016, cujo retrocesso se aprofunda com um governo autoritário de extrema direita. Se Paulo Freire, em Educação e atualidade brasileira, considerava a educação um instrumento de crucial importância para promover a passagem da consciência popular do nível transitivo-ingênuo ao nível transitivo-crítico, evitando sua queda na consciência fanática, quando retoma essa análise, na redação de Educação como prática da liberdade, ele constata que a queda no fanatismo havia se consumado em decorrência da instalação da ditadura militar. Hoje, podemos considerar que o fanatismo também prevaleceu, instalando-se em consequência do golpe de 2016 e instituindo um clima de ódio por iniciativa de uma elite que conseguiu instilá-lo em parte da própria população por meio das chamadas fake news, as quais, usando largamente as redes sociais, converteu mentira em estratégia eleitoral e tática de governo. Felizmente, tudo indica que a maior parte da população, por meio de suas organizações, vem resistindo à política antipopular e antinacional que se instalou pós-eleições de 2018. É imperioso, pois, que essa mobilização seja vitoriosa em 2022 para estancarmos o processo de destruição em curso. Sem isso, o resultado será um novo exílio das ideias e propostas político-educativas esposadas por Paulo Freire e assumidas pelas entidades representativas dos diversos segmentos da classe trabalhadora.

\section{Referências}

ÁVILA, F. B. Neocapitalismo, socialismo, solidarismo. Rio de Janeiro: Agir, 1963.

ÁVILA, F. B. Solidarismo. 3. ed. Rio de Janeiro: Agir, 1965.

FREIRE, A. M. A. Paulo Freire: uma história de vida. Indaiatuba: Villa das Letras, 2006.

FREIRE, P. Educação e atualidade brasileira. Tese apresentada no concurso para a cadeira de História e Filosofia da Educação da Escola de Belas Artes. Universidade Federal de Pernambuco, Recife, 1959.

FREIRE, P. Conscientização e alfabetização: uma nova visão do processo. Estudos Universitários, Recife, n. 4, p. 5-24, abr./jun. 1963.

FREIRE, P. Educação como prática da liberdade. 4. ed. Rio de Janeiro: Paz e Terra, 1974.

FREIRE, P. Accion cultural para la libertad. Buenos Aires: Tierra Nueva, 1975.

FREIRE, P. Ação cultural para a liberdade e outros escritos. Rio de Janeiro: Paz e Terra, 1976.

FREIRE, P. Cartas à Guiné-Bissau: registros de uma experiência em processo. Rio de Janeiro: Paz e Terra, 1977. 
FREIRE, P. Conscientização: teoria e prática da libertação - uma introdução ao pensamento de Paulo Freire. São Paulo: Editora Moraes, 1980.

FREIRE, P. A educação na cidade. São Paulo: Cortez, 1991.

FREIRE, P. Pedagogia do oprimido. 46. ed. Rio de Janeiro: Paz e Terra, 2005.

FREIRE, P. Pedagogia da autonomia. 36. ed. esp. Rio de Janeiro: Paz e Terra, 2007.

FREIRE, P. Pedagogia do Oprimido (o manuscrito). Organização Jason Ferreira Mafra, José Eustáquio Romão e Moacir Gadotti. São Paulo: Editora e Livraria Instituto Paulo Freire/Universidade Nove de Julho/ Ministério da Educação, 2013. Edição fac-símile do manuscrito original.

GOLDMANN, L. Ciências humanas e filosofia. São Paulo/Rio de Janeiro: Difel, 1976.

PAIVA, V. P. Paulo Freire e o nacionalismo-desenvolvimentista. Rio de Janeiro/Fortaleza: Civilização Brasileira/Edições UFC, 1980.

SAVIANI, D. Interlocuções pedagógicas: conversa com Paulo Freire e Adriano Nogueira e 30 entrevistas sobre educação. Campinas: Autores Associados, 2010.

SAVIANI, D. História das ideias pedagógicas no Brasil. 6. ed. Campinas: Autores Associados, 2021.

\section{Sobre o Autor}

Dermeval Saviani é graduado em Filosofia (1966) e Doutor em Filosofia da Educação (1971) pela Pontifícia Universidade Católica de São Paulo (PUC-SP). É Professor Emérito (2002) da Universidade Estadual de Campinas (Unicamp), Pesquisador Emérito do CNPq (2010) e Doutor honoris causa pela Universidade Tiradentes de Sergipe (maio de 2017), pela Universidade Federal da Paraíba (novembro de 2017) e pela Universidade Federal de Santa Maria (agosto de 2020). Atualmente, continua atuando como Coordenador Geral do HISTEDBR e como Professor Titular Colaborador Permanente do Programa de Pós-graduação em Educação da Unicamp, na Linha de Pesquisa 6: Filosofia e História da Educação.

Recebido: 3 ago. 2021 